

\section{O duplo e a ilusão no filme Clube da Luta}

\section{Double and illusion in the movie Fight Club}

\author{
Rogério de Almeida' ¿
}

\section{Resumo}

O objetivo deste artigo é refletir sobre a temática do duplo presente no filme Clube da Luta e sua relação com o corpo físico (indivíduo) e o fenômeno pós-moderno (sociedade), por meio da noção de ilusão. A insatisfação frente a existência é a força motriz da ilusão, que consiste em duplicar o que é único para se proteger de um real indesejável. Essa fórmula sintetiza, de certo modo, as representações postas em jogo na obra cinematográfica em questão.

\section{Palavras-chave}

Duplo; pós-moderno; real-ilusão.

\section{Abstract}

The aim of this article is to reflect on the theme of the double in the movie Fight Club and its relationship to the physical body (individual) and the postmodern phenomenon (society), through the notion of illusion. Dissatisfaction of the existence is the driving force of ilIusion, that duplicates what is only one for protect the real undesirable. This formula summarizes, in a sense, the representations put into play in the movie.

\section{Keywords}

Doble; post-modern; real-ilusion. 


\section{Introdução}

Baseado no livro homônimo de Chuck Palahniuk, o filme Clube da Luta (Fight Club, David Fincher, 1999) causou polêmica quando foi lançado em 1999 e mesmo permanecendo pouco tempo em cartaz tornou-se um filme cultivado pela crítica, provavelmente pelo fato de que parece representar uma dada época, com determinados valores, crises e formulações estéticas.

Pode-se mesmo ver no filme uma atualização da $L a-$ ranja Mecânica (Clockwork Orange, Stanley Kubrick, 1971), a falência histórica de uma dada ordem social, uma bem acabada fábula da distopia ou contrautopia contemporânea ou mesmo a era da frustração (Ribeiro, 2002). Certamente há algo de desconcertante que vai além da estetização da violência ou do anúncio de que o mal-estar da civilização continua, ainda que por vias pós-modernas.

Sem invalidar ou mesmo pôr em análise essas visões, meu objetivo é refletir sobre a insatisfação diante da existência (e consequentemente do real), a ponto de se buscar um duplo que a (ou o) substitua. Trata-se do tema da ilusão, dos artifícios - (in)conscientes, (pre)meditados, psicológicos, ideológicos - para se fugir da singularidade do real, para se escapar da fatalidade do único.

\section{Vamos acabar com a civilização para construir um mundo melhor}

O filme começa com uma cena típica de tensão, um homem apontando a arma para a própria boca, para logo nos enviar, com o recurso do flashback, para onde tudo começou. O narrador assume a condução das lembranças de sua própria vida e, sem se nomear, passa a caracterizar o seu mal-estar: à medida que realiza os sonhos de consumo propagados pela publicidade, sua vida, em vez de felicidade, encontra uma crescente e

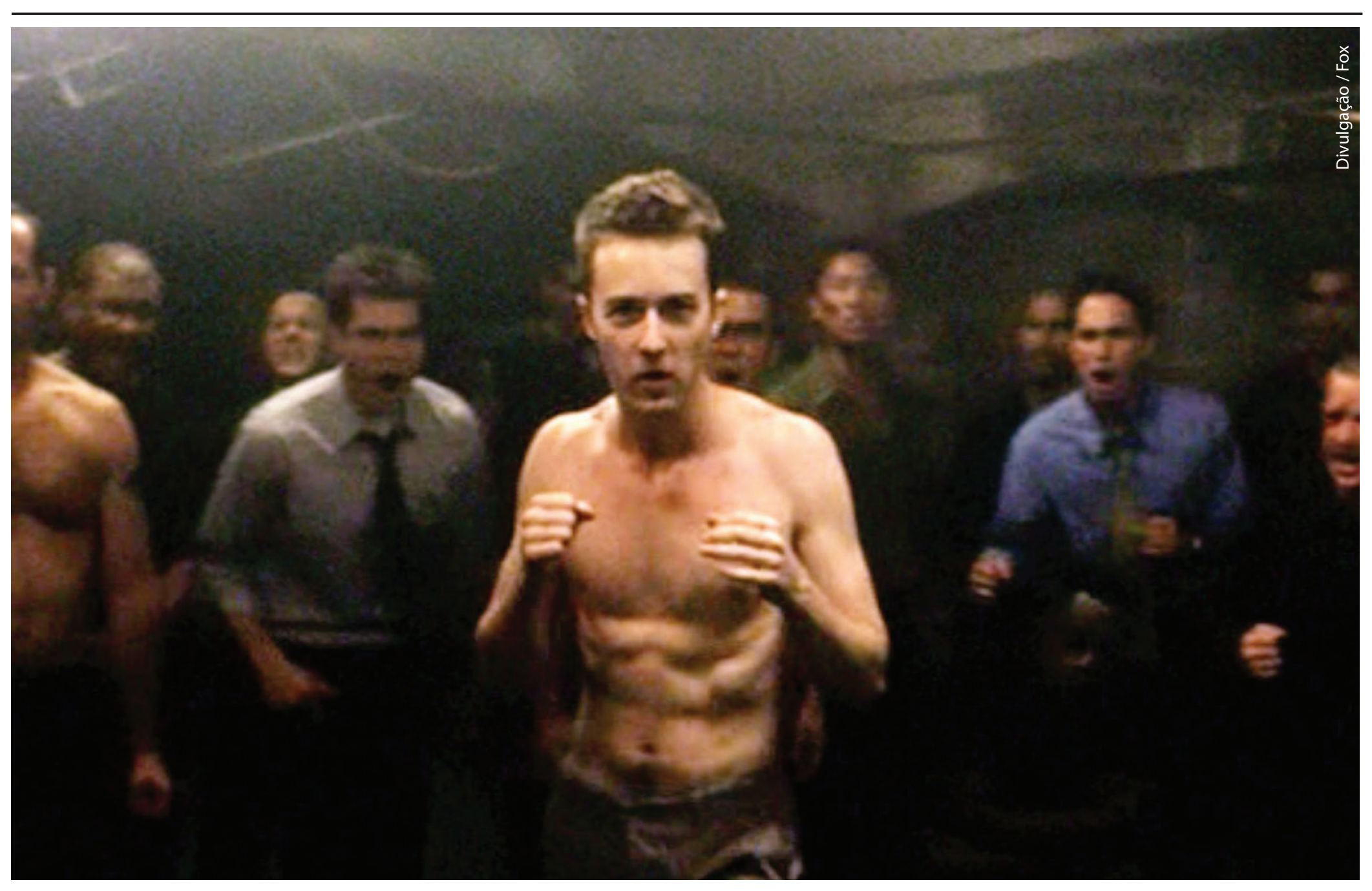

passiva insatisfação. A crítica ao consumismo é direta: você não é o que consome, seu nome não é o da etiqueta. No entanto, não sabemos como se chama o protagonista. Por inferência - já que constantemente o narrador se refere a si mesmo como "uma parte" de Jack (no livro de Palahniuk é Joe) - o chamaremos de Jack.

Jack trabalha numa empresa de seguros e não gosta do seu trabalho, em parte por enganar os clientes, em parte pela rotina. É um sujeito anônimo, pacífico, solitário, conformado e que busca se satisfazer no con- sumo, enchendo sua casa de objetos que o situam em determinado estilo de vida e grupo social. Até que é acometido de insônia. O médico lhe recomenda, em resposta ao seu pedido por um remédio para dormir e com a alegação de que ele descobrirá o que é sofrimento, visitar grupos de apoio a doentes de câncer. A experiência funciona de maneira catártica. Depois de chorar no ombro de pessoas doentes, ele consegue descansar. Mas então Jack conhece Marla Singer, uma mulher suicida, que zomba constantemente da mor-

27 PORTO ALEGRE | v. 19 | n. 32 | 2014 | pp. 26-34 Sessões do Imaginário 
te, e que frequenta os grupos com o mesmo propósito que ele. Um reconhece a falsidade do outro e passam a ter uma relação de atração/repulsão.

Em uma de suas viagens de rotina, Jack conhece Tyler Durden, um sujeito que fabrica sabão, é garçom e projecionista em uma sala de cinema. Quando retorna ao seu apartamento, Jack descobre que uma explosão o destruiu completamente, sai com Durden para beber e, depois de filosofarem sobre a vida, decidem amigavelmente trocar alguns socos. A violência gera paz e a prática logo se propaga. Está fundado o clube da luta, com encontros clandestinos e oito regras: 1) Não se fala sobre o Clube da Luta; 2) Não se fala sobre o Clube da Luta; 3) Quando alguém disser "pare" ou perder os sentidos a luta acaba; 4) Só dois caras em cada luta; 5) Uma luta de cada vez; 6) Sem camisa, sem sapatos; 7) As lutas duram o tempo que for necessário; 8) Se essa é a sua primeira noite no Clube da Luta, você tem que lutar.

A segunda regra é uma repetição da primeira e tem um efeito irônico, pois a reiteração deveria funcionar para garantir o seu cumprimento, mas é efetivamente a única que não é seguida, pois diariamente o clube adquire novos membros, como aliás seria de se supor, quando se considera a oitava regra. Mas o "não se fala sobre o Clube da Luta" assinala, também, o caráter secreto do clube, que se instaura como um duplo da sociedade que, de modo inverso à publicidade e ao consumo de objetos, é sigiloso e voltado ao dispêndio.

Jack e Durden passam a residir em uma mansão abandonada e destruída, com vazamentos e sem eletricidade. Fazem sabonete da gordura humana retirada por lipoaspiração e jogada no lixo, fabricam bombas, testam seus limites derramando ácido sobre a mão e cultivam uma espécie de bem-estar por meio da (auto) agressão. Jack, que passa a trabalhar com o rosto constantemente machucado, discute com seu chefe e, após agredir a si mesmo, simulando ter sido espancado por seu superior, consegue um acordo que lhe permite receber seu salário sem precisar trabalhar.

Tyler Durden envolve-se, para insatisfação de Jack, com Marla Singer, e transforma o clube da luta em um empreendimento mais ambicioso, o Projeto Caos. Com o objetivo de sabotar a sociedade, cada integrante do clube é incumbido de realizar uma tarefa, como dar laxante a pombas para sujarem os carros, alterar códigos de barra nos supermercados, destruir monumentos etc. Uma cena marcante é quando Durden aponta uma arma para a cabeça de um atendente de loja e o incita a realizar seu sonho profissional. Aterrorizado, o jovem concorda em voltar a estudar no dia seguinte. O que parece mover o Projeto Caos é a esperança de que as pessoas "acordem" para uma realidade esquecida diante do torpor ideológico que assolaria a sociedade de consumo.

Por outro lado, a constituição do Projeto Caos se dá por meio do recrutamento de um exército que obedece cegamente às ordens de seu líder, com características típicas dos regimes totalitários e das organizações terroristas. Jack passa a discordar de Durden, até que um dia, ao chegar em casa, a descobre vazia. Passa então a persegui-lo, viajando pelas variadas cidades que possuem um clube da luta, mas não o encontra. Quando Jack chega, Durden acabou de partir.

Assim como no Édipo Rei, de Sófocles, ou em William Wilson, de Edgar Allan Poe, Jack descobre que o tempo todo ele buscava a si mesmo. Jack e Durden são, na verdade, a mesma pessoa. Em cenas rápidas, assistimos suas rememorações, nas quais aparece batendo em si mesmo, fazendo sexo com Marla, recru- tando seu exército etc. Jack e Durden são a mesma pessoa, mas a mudança de perspectiva não encerra a história. Jack continua perseguindo Durden, que comandou a instalação de bombas em todos os prédios de operadoras de cartão de crédito, para que o controle de todas as dívidas seja perdido, instaurando o caos no sistema financeiro.

Após seguidas cenas de luta entre os dois, em que uma câmera neutra mostra Jack batendo em si mesmo (de inegável efeito cômico), chegamos à cena inicial do filme, em que Jack aponta uma arma para sua própria boca. Depois de desferir o tiro que mata Durden, Jack sopra a fumaça da boca e segura a mão de Marla, enquanto ambos contemplam pela janela envidraçada de um prédio a destruição ao redor. A última fala de Jack (aparentemente restituído à sua identidade única) é para Marla: "Você me conheceu numa época estranha da minha vida".

O livro, diferente do filme quanto ao final, narra brevemente e de maneira oblíqua a estadia do narrador, depois do disparo, no que seria o Céu, embora a ambiguidade do texto permita interpretá-lo como um hospital ou um hospício. Duas frases resumem bem a insatisfação quanto à existência: "Foi muito melhor que a vida real", em relação à sua (pretensa) morte, e "Vamos acabar com a civilização para construir um mundo melhor" (Palahniuk, 2000).

Aliás, esta última frase poderia sintetizar as pretensões "filosóficas" tanto do livro quanto do filme. Trata-se, no fundo, de um argumento suficientemente explicitado por Camus (2008): todo homem revoltado é um idealista, ama o que não existe. Vamos acabar com a civilização (revolta) para construir um mundo melhor (idealismo). O desejo de construir um mundo melhor (melhor para 
quem?) será sempre, e antes de tudo, uma denegação do real. A (minha) vida não é suficiente. O mundo (para mim) não deveria ser assim. Vamos acabar com a civilização...

\section{Mal-estar, era do vazio,}

tempo das tribos etc.

Não devemos falar do clube da luta. Essa regra, aliás a primeira e a segunda do clube, parece contradizer todas as expectativas de cura pela fala ou pela autocompreensão do que se faz, do que se pensa, de como se decide. A violência no clube da luta não está ligada a uma certa selvageria pré-civilizatória que tenderia a solucionar os conflitos na porrada por falta de condições de resolvê-los pacificamente, por meio de qualquer outro método que não agredisse diretamente o corpo. O clube da luta é uma reunião amigável de parceiros que comungam ritualmente uma terapia pela porrada. Nesse sentido, o que tem de menos metafórico no filme é o clube.

O clube surge por acaso, quando Jack e Durden resolvem trocar socos e se sentem bem. Depois saberemos que se trata de Jack desferindo golpes em si mesmo, mas isso não altera a fundação do clube, que passa a congregar pessoas que redescobrem o bem-estar por meio da agressão física.

Se nos grupos de apoio aos doentes Jack encontrou satisfação na dor alheia, o clube será sua continuidade, mas em outro grau de profundidade. Não se trata mais de partilhar uma dor psíquica advinda de uma doença física, como era o caso de Bob, que perdera os testículos e ganhara mamas em decorrência de um câncer, mas de partilhar uma dor física como forma de se sentir vivo, conectado com a realidade.

Não é masoquismo ou sadismo, mas narcisismo. Os hematomas estampados no rosto passam a ser osten- tados como uma marca exclusiva, um produto que os consumistas não podem consumir. O novo modo de vida se torna, então, uma alternativa à frustração de não se atingir a felicidade, a plenitude, a perfeição por meio do trabalho, do consumo e da vida civilizada, tal como é prometido pela ideologia liberal.

Nesse sentido, a contraideologia, como forma de resistência, e depois de luta, retoma de maneira provocativa o cerne mesmo do que Freud (1974) compreendeu como mal-estar na civilização: o princípio de crueldade, o instinto de morte, a violência que irrompe no homem e na sociedade, na intensidade proporcionalmente inversa com que se quis extirpá-la. Mas como notou Ribeiro (2002, p. 230), "não há um certo romantismo na violência que possa ser autoproclamado como um estágio transgressivo rumo a uma determinada redenção". A violência é estetizada, é apresentada como a realização de um desejo que, de acordo com as regras da nossa sociedade, é impossível de realizar.

Ainda segundo Ribeiro (2002, p. 232), o filme portaria uma "contrautopia que faz que os indivíduos possam ou viver na obscuridade, alimentando sonhos de consumo e continuando a ser invisíveis ao mundo, ou aceitem alguma saída messiânica negativa, totalitária". De qualquer modo, é a permanência da equação do mal-estar proposta por Freud: a impossibilidade de conduzir o impulso vital de modo racional faz com que se volte contra si como pulsão de morte.

E é compreensível que Ribeiro (2002, p. 233) conclua reafirmando que o filme não é uma representação de nossa época, mas sim um sintoma.

O sintoma mais intenso que o filme parece apontar a meu ver e a despeito de todas as circunstâncias históricas e ideológicas da atualidade, é a insatisfação com o real, o desejo de substituí-lo por um duplo qualquer, de dotá-lo de um significado engrandecedor, que possa dar um sentido à existência para além dela própria. Essa percepção de que a realidade não é suficiente, de que o real não é como se deseja, gera tanto um deslocamento ideológico quanto a duplicação da personagem.

Deslocamento ideológico, distopia, contrautopia ou contraideologia - os termos são fartos, mas o fenômeno é o mesmo. Trata-se da tentativa de anular, combater ou desvalorizar o real afirmando que ele poderia ser de outro modo. Aqui, num primeiro momento, pouco importa a forma atual que ele assuma, desde que se declare que ela é insuficiente e, portanto, necessita ser transformada. É essa a lógica que está por detrás das ações de Tyler Durden, frente ao descontentamento vivido por Jack e materializado em sua insônia.

Aliás, sua insônia, como sintoma, indica a impossibilidade de dormir sem que se esteja em paz. Essa "paz de espírito" seria alcançada por um mecanismo conhecido, suficientemente descrito por Freud (1974), e que consiste em satisfações passageiras alcançadas por meio da liberação de uma tensão. No caso, a liberação primeira é alcançada quando Jack chora abraçado aos infortunados pela doença, depois substituída pelo clube da luta.

A questão ideológica, inclusive, é um bom exemplo de como essa lógica, que intenta desautorizar a existência, funciona. Acusa-se a ideologia de esvaziar o sentido da vida substituindo-o pelo ideal de uma felicidade que só seria atingida por meio do trabalho e do consumo. E, de fato, a ideologia reinante apregoa, para o funcionamento de suas estruturas e sistemas, justamente isso. No entanto, explicitar essa ideologia, combatê-la, inverter a sua lógica parece não ser suficiente para transformar a existência, modificar a singularidade do real. Seu único efeito é substituir uma ideologia por outra. Pode-se trocar de roupa, mas o corpo é o mesmo. Daí o efeito similar, embora os valores 
sejam opostos, da contraideologia: a incapacidade de reduzir a vida (e o real) a um conjunto qualquer de ideias, seja para diagnosticá-la, defini-la ou mesmo conduzi-la.

A duplicação do protagonista e seu retorno à unidade apontam para a mesma fórmula. Seu desejo de ser outro, ou melhor, de ser ele mesmo diferente de como é, ilustra esse processo em que a ilusão, na impossibilidade de apagar ou transformar o real, o duplica, de modo que ele seja ele mesmo e outra coisa qualquer.

Nesse sentido, é sintomática a leitura que Lipovestky $(1989$, p. 13) faz das sociedades contemporâneas:

Sociedade pós-moderna significa, neste sentido, retracção do tempo social e individual precisamente quando se impõe cada vez mais a necessidade de prever e organizar o tempo colectivo, exaustão do impulso modernista dirigido para o futuro, desencanto e monotonia do que é novo, esgotamento de uma sociedade que conseguiu neutralizar na apatia aquilo que a fundamenta: a mudança. Os grandes eixos modernos, a revolução, as disciplinas, o laicismo, a vanguarda, foram desafectados à força da personalização hedonis ta, o optimismo tecnológico e científico desmoro nou-se, enquanto as inúmeras descobertas eram acompanhadas pelo envelhecimento dos blocos, pela degradação do meio ambiente, pelo apagamento progressivo dos indivíduos, já nenhuma ideologia política é capaz de inflamar as multidões, a sociedade pós-moderna já não tem ídolos nem tabus, já não possui qualquer imagem gloriosa de si própria ou projecto histórico mobilizador; doravante o vazio que nos governa, um vazio sem trágico nem apocalipse.
Para Lipovetsky, há em curso um processo de personalização que desde a Segunda Guerra vem se intensificando, tornando a sociedade cada vez mais individualista, daí o esvaziamento dos valores modernos e coletivos, daí a ruptura com as sociedades disciplinares, universalistas, coercitivas, para a instalação de uma sociedade flexível, baseada na informação e na estimulação dos desejos, com valores hedonistas, respeito pelas diferenças, culto da liberdade pessoal, da expressão livre. Assim, a sociedade deixa de se caracterizar pela coletividade, que mergulhava o indivíduo numa rede de regras uniformes - vida política, produtiva, escolar, moral - cujas convenções sociais subordinavam os valores individualistas aos sistemas de organização e sentidos disciplinados, e passa a se constituir por processos que valorizam o livre desenvolvimento da personalidade íntima, a realização pessoal, a singularidade subjetiva, as quais não serão mais vigiadas (se quisermos remeter a uma terminologia foucaultiana), mas controladas.

Em Clube da Luta reconhecemos esse processo, em que o indivíduo transita livremente pela esfera econômica e social, desde que sua atuação seja de consumo e não política. E se Lipovestky mostra como se sai do social para se chegar ao indivíduo (e ao individualismo), o filme parte do narcísico, do individualismo exacerbado e doentio (Jack socando a si próprio), para compor o primeiro gérmen coletivo, o clube da luta, que logo se ampliará para o Projeto Caos. No clube, encontros noturnos, com local fixo e hora marcada, em que o indivíduo rememora uma dada ordem social, em que o individualismo se retrai. Já no Projeto Caos, um passo adiante, o apagamento do indivíduo (ninguém tem nome) e de sua vida cotidiana, para o insulamento na organização paralela, terrorista, que buscará sabotar a sociedade por meio de uma ação de grupo.
Na contramão do pensamento lipovestkiano, Maffesoli (1998) entende que esses agrupamentos, como o clube da luta ou o Projeto Caos, sinalizariam o retorno das tribos, o declínio do individualismo moderno, o ressurgimento de um "dinamismo societal" que atravessaria o corpo social e se afirmaria em microgrupos que se criam menos para essa ou aquela finalidade e mais pelo prazer de estar junto. Buscando escapar da lógica do "dever ser", que apregoa que devemos julgar a partir do que está instituído, o sociólogo afirma que "a constituição em rede dos microgrupos contemporâneos é a expressão mais acabada da criatividade das massas" (Maffesoli, 1998, p. 137).

Mais à frente, na página 140 de O Tempo das Tribos, Maffesoli concluirá, depois de citar os eventos de consumo exacerbado, de reuniões esportivas, de aglomerações de férias ou shows musicais, que "existe um constante movimento de vaivém entre as tribos e a massa [que] se inscreve num conjunto que tem medo do vazio". Não é preciso insistirmos na argumentação para se constatar como Maffesoli e Lipovetsky se situam, conquanto o objeto seja o mesmo, em pontos extremos de análise. $\mathrm{O}$ tom negativo de um cede lugar a uma visão encantada das tensões contemporâneas. Assim, "modos de vida estranhos uns aos outros podem engendrar, em pontilhado, uma forma de viver em comum" (Maffesoli, 1998, p. 142).

De uma forma ou de outra, o fato é que ambos parecem ter razão, ainda que parcialmente, quando tomamos o filme Clube da Luta como sintoma de uma paisagem contemporânea que se desenha (portanto, sem o distanciamento possível de quem vê um tempo acabado). Parcialmente, porque esse modo de vida construído no filme como alternativa ao consumismo e ao individualismo não aceita engendrar "uma forma de viver em 
comum" com o que the é estranho. Pelo contrário, sua lógica é moderna, revolucionária, não aceita as diferenças e quer apagar o que lhe é estranho. Daí as ações de sabotagem, as táticas de guerrilha, o desejo de destruir o sistema financeiro e, consequentemente, a ordem instituída. Por outro lado, há uma coesão interna no grupo que transcende qualquer discurso racional, uma partilha que vai além de qualquer ideologia, que se sustenta, justamente, num vínculo emocional, numa dinâmica tribal.

A insônia e, depois, o distúrbio de personalidade do protagonista são os sintomas de uma sociedade doente, debilitada, incapaz de fornecer os meios pelos quais o homem possa encontrar sua felicidade. Aos olhos de Jack, de Tyler Durden (seu duplo) e de Marla Singer, o mundo vivido (o real) é uma ilusão, é insuficiente, uma sombra distorcida de um real verdadeiro (o projeto moderno? um homem primevo pré-moderno?) que se perdeu em algum momento da história. Daí a necessidade de destruir uma determinada ordem de convenções (econômica, publicitária, política, financeira, social) para que vida verdadeira possa ser vivida.

Trata-se, em outras palavras, de desvalorizar a existência que se tem, como se percebe na fala de Tyler Durden:

A propaganda põe a gente pra correr atrás de carros e roupas. Trabalhar em empregos que odiamos para comprar merdas inúteis. Somos uma geração sem peso na história. Sem propósito ou lugar. Não temos uma Guerra Mundial. Não temos a Grande Depressão. Nossa guerra é a espiritual. Nossa depressão são nossas vidas.

Busca-se uma ordem qualquer que sirva de referência para a existência: publicidade, trabalho, história. Na ausência de um princípio ou finalidade que oriente a vida para uma realização qualquer, constata-se que "seu emprego não é o que você é, nem quanto ganha ou quanto dinheiro tem no banco. Nem o carro que dirige. Nem o que tem dentro de sua carteira. Nem as calças que veste. Você é a merda ambulante do mundo". Mas se a identidade social não é capaz de dizer o que somos, quem poderia dizer? Tyler nos incita a lutar, a sair do apartamento, a provar que estamos vivos, apela a um valor humano que precisa ser encontrado como forma de preencher o vazio da vida. Mas que valor seria esse? De que luta precisaríamos para nos tornarmos melhor? O que seria esse melhor? Enfim, o discurso negativo de Durden contra a existência prolifera na mesma medida em que silencia sobre sua alternativa. É como se a vida devesse ser qualquer coisa diferente do que é, como se qualquer outra vida (só pelo fato de ser outra) pudesse ser melhor (e, portanto, mais desejável) da que temos.

Seguindo a fórmula proposta pelo filme, Jack busca satisfazer sua existência em outro lugar fora dela mesma: inicialmente, no consumo, o qual gera mais insatisfação; depois, quando essa insatisfação passa a se exprimir pela insônia, no grupo de doentes; depois, no desdobramento de sua personalidade em outra (Tyler Durden); na sequência, no clube da luta, no Projeto Caos, na explosão do sistema financeiro, em que destruição e autodestruição são claras respostas a um ódio, cada vez mais generalizado, à sua vida particular e à existência de modo geral.

Em todas essas passagens, a mesma ilusão do duplo, que consiste em tornar dois o que é um, como se fosse possível que outra instância qualquer fundamentasse o desejo de sentido, de ordem e de grandiosidade que não se encontra no que é único, singular e sem sentido (o real, a existência). O que motiva Clube da Luta, seja o livro ou o filme, é um pensamento bastante comum, que con- siste na desvalorização da vida, na denegação do real, na insatisfação diante da existência. O que é incomum é a intensidade desse ódio, manifesto na agressão contínua e cada vez mais potencializada ao próprio corpo.

\section{Corpo único, persona dupla}

O tema do duplo é um dos mais inquietantes, principalmente quando o que se duplica é o próprio homem. Inquietante porque impossível: não há dois homens iguais. Mas inquietante também porque seu fantasma segue vivo e rondando nossas representações. Não à toa o fascínio pelo gêmeo e, mais recentemente, pelo clone. Mas essa duplicação corporal é, como dissemos, impossível. A semelhança do gêmeo, do sósia ou mesmo do clone é apenas uma ilusão, uma duplicação de superfície, como a do espelho. Apresentam a mesma aparência, mas são pessoas diferentes, corpos diferentes, são expressões de uma unicidade, como tudo o que é real.

Entretanto, há outro tipo de duplo, expresso principalmente pelo imaginário das artes, da filosofia, da psicologia, que é a duplicação do "eu". Nesse tipo de duplo, a identidade, o sujeito ou a alma torna-se volátil, intermitente, como se duas personas habitassem um único corpo, podendo se desligar dele ou a ele retornar simultânea ou alternadamente. É como se corpo e alma fossem duas realidades diferentes, subjugadas por regras diferentes e afetadas de maneira diferente. A respeito, vale a pena pensar na inversão de hierarquia proposta pelo poema Momento num café, em que um homem fez um gesto largo ao enterro que passava, pois sabia, nas palavras de Manuel Bandeira (2009, p. 155), que:

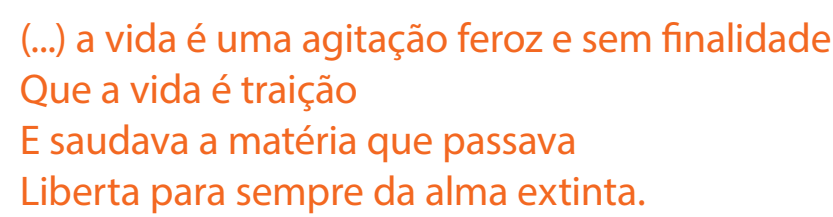


Essa fórmula de Bandeira, aliás, inverte o desejo de toda consciência, que, de acordo com Unamuno (1996), não deseja outra coisa que não sua própria permanência. Aí estaria, segundo ele, um aspecto importante do que se almeja como vida depois da morte, que é a continuidade, a despeito da impossibilidade física, da consciência que se tem enquanto vivo.

De fato, parece não valer muito o consolo de que continuaríamos na memória da família, nos genes dos filhos ou no húmus do mundo. Quem quer perdurar é a consciência que responde por um eu, que dá continuidade histórica aos fatos, aos instantes vividos, que responde por uma memória, por um sentido, um direcionamento na existência.

A constatação de que a matéria se liberta da alma e não esta daquela atesta que a existência é frágil, efêmera e desastrosa, pois quando alguém morre, deixa de existir o que era único e, por isso, também insubstituível. E a morte muitas vezes chega cedo, sem razão, sem sentido e sem tempo para se escapar dela. Fica o corpo sem vida, mas por estar sem vida, já de nada serve. A alma que o animava, isto é, a vida que o corpo possuía se extinguiu. Nesse sentido, é o corpo que comanda, dirige, domina a alma, seja ela compreendida como mente, consciência, sujeito, identidade, self etc. e não o oposto. Tal inversão de perspectiva altera toda a história do pensamento ocidental, que, salvas raríssimas exceções, subordina o corpo, sempre desvalorizado, à alma. Além do desejo que nossa consciência tem de sobreviver ao corpo e, portanto, crer que a alma seja eterna e imutável compreende-se também essa duplicação corpo-alma do ponto de vista da observação, quando se constata que o cadáver, semelhante a um títere, a uma marionete, já não tem quem Ihe manipule as "cordinhas".
Foi Clément Rosset (2008, p. 110-111) quem demonstrou que a crença na existência de fantasmas é menos fruto da imaginação que da lógica, já que, diante de um cadáver, reconhecemos o corpo, mas não o resto, que desapareceu. Isso que desapareceu é visto como algo que não era corpo, portanto como um espírito, uma alma, uma consciência que animava o corpo, que lhe dava vida e que agora se ausentou. Portanto, o fantasma do morto, desprendido do corpo, habita o invisível, permanece como duplo.

Este, aliás, seria o duplo por excelência: a crença de que somos simultaneamente uma alma e um corpo (ou de que somos alma habitando um corpo). Descartes postulará que o corpo é de natureza animal enquanto a alma de origem divina, portanto um perece com a morte, mas a outra é eterna, tal como o deus que a criou. Visão cristã, decerto, mas que também encontra correlatos ateístas numa ciência que situa o "eu" ou o "self" como um processo cerebral (e que poderia ser restabelecido fora do corpo material) ou como um produto que, se alimentado pela vida, pode ser religado (como atestam os casos de congelamento de corpos à espera de uma ciência que possa lhes restituir a vida).

Seja como for, sempre que se considera o corpo como receptáculo, invólucro, como sede do "eu" ou da alma, está se procedendo a uma duplicação metafísica do que é único e a uma desvalorização compulsória do corpo, que passa a ser objeto de um sujeito que o tratará como outro. Daí as autopunições, os autoflagelos ou, caso do Clube da Luta, a autodestruição como formas de tentar restabelecer o domínio sobre o que escapa ao controle. A alma, portanto, como duplo eterno e incorpóreo do corpo, tem o dever de subjugá-lo, mesmo que seja para seu próprio bem-estar (uma noite agradável de sono depois de uma sessão de socos e pontapés).
O que assistimos, no caso do Clube da Luta, é o desdobramento da luta: luta física entre dois corpos, luta de um exército contra a sociedade, luta de um homem consigo mesmo, luta da alma contra o corpo, luta de duas personalidades pelo domínio do corpo... Enfim, a luta da ilusão para duplicar o que é único: desejo de outro mundo (duplo do real), desejo de outra vida (duplo da personalidade).

Entretanto, no caso do filme, não se trata de uma ilusão simples, dessas que se encontram fartamente e que consiste em duplicar o que se observa para afastar do duplo a parte indesejável. "Na ilusão, quer dizer, na forma mais corrente de afastamento do real, não se observa uma recusa de percepção propriamente dita. Nela a coisa não é negada: mas apenas deslocada, colocada em outro lugar" (Rosset, 2008, p. 17). Como ocorre, por exemplo, em O Retrato de Dorian Gray, romance de Oscar Wilde, em que o quadro envelhece enquanto o protagonista permanece jovem; poderíamos pensar também, para ficarmos no Brasil, no conto $O$ Espelho: esboço de uma nova teoria da alma humana, de Machado de Assis e no Espelho de Guimarães Rosa. Em todos esses casos literários, o duplo funciona como deslocamento: o que é único se duplica, de modo a se valorizar apenas uma parte do duplo, sem que haja confusão ou duplicação da personalidade. No caso do filme, a ilusão é psicopatológica e seus casos são chamados de desdobramento de personalidade (esquizofrênica ou paranóica). É o caso de o médico e o monstro (Stevenson) ou do William Wilson, de Edgar Allan Poe.

Aliás, o filme se parece bastante com este último, seja na cena de reconhecimento, em que o duplo se mostra único, seja no desfecho, em que um tenta matar o outro. Leiamos o final do conto de Poe $(1989$, p. 
125), em que o duplo de Wilson diz a ele: "Você venceu, e eu pereço. Mas daqui para o futuro também você estará morto. Morreu para o mundo, para o céu e para a esperança! Existia em mim. Olhe bem agora para a minha morte, $e$ nessa imagem - que é a sua - você verá o seu próprio suicídio!". Em Poe, a descoberta de William Wilson de que o outro era ele mesmo coincide com seu suicídio. A restituição ao único se dá com a morte dos dois. Em Clube da Luta, a diferença reside no fato de que Jack, quando atira em Tyler, acaba por matar apenas o duplo, restabelecendo o único (o corpo que vemos na última cena é o de Jack, mas a personalidade é a de Tyler). Assim, a atitude extremada contra o próprio corpo (desferir um tiro na boca) sela a restituição do duplo ao único.

Como afirma Rosset (2008, p. 119), a ilusão reenvia

para uma mesma função, para uma mesma estrutura e para um mesmo fracasso. A função: proteger do real. A estrutura: não recusar perceber o real, mas desdobrá-lo. O fracasso: reconhecer tarde demais no duplo protetor o próprio real do qual se pensava estar protegido. Esta é a maldição da esquiva: reenviar, pelo subterfúgio de uma duplicação fantasmática, ao indesejável ponto de partida, o real.

Por mais que Jack tenha procurado se proteger do real desdobrando-se inconscientemente em Tyler, no final é obrigado não só a lidar com esse real, mas a lutar contra seu duplo, ou seja, contra a ilusão que ele mesmo criou. Mas Tyler não foi sempre Jack? O real não esteve sempre ali?

Tão familiar e tão estranho a mim, o meu duplo é o que me possibilita ao mesmo tempo me distanciar de mim e me encontrar. $O$ duplo é a revelação de que sou desconhecido de mim mesmo. Mas ao descobrir que não me conheço, passo a me conhecer. O que descubro, no entanto, não é minha identidade original, minha alma verdadeira ou minha substância, mas justamente o inverso: o caráter instável, provisório e efêmero da minha identidade (ou disso que chamo de eu). O duplo possibilita, então, não a compreensão de que eu não sou nada (numa vertente negativa), mas que eu sou nada (afirmação). Ou que sou apenas no tempo presente, sem garantia de que o passado foi como creio que tenha sido ou que o futuro certamente virá. Há uma expressão em português que conota isso: há quem prefira dizer "estou isso" do que "sou isso". De fato, sempre estamos, nada somos.

Quando Jack descobre que Tyler Durden não existe, descobre simultaneamente que ele próprio não existe, pois todos veem nele não Jack, mas Tyler. Mas não veem o Tyler que ele, Jack, via, pois o corpo de Tyler é o mesmo de Jack. Duas personas, um só corpo.

Entretanto, se em Édipo Rei - caso mais famoso de coincidência entre investigador e investigado - ou mesmo em William Wilson a revelação do duplo restitui o único, o mesmo não ocorre em Clube da Luta, cuja revelação desencadeia uma nova sessão de luta. Portanto, quando Jack descobre que Tyler é seu duplo, nada se altera quanto à existência desse duplo. Ou seja, revelar uma ilusão não é suficiente para extingui-la.

A implicação disso não parece pequena, se tomarmos por base que as ações contraideológicas ancoram-se num pressuposto educacional de que a revelação de uma falsidade ideológica deveria bastar para o seu combate. Assim, numa lógica marxista, o proletário, ao tomar ciência de sua situação de explorado, reagiria contra a exploração dos meios de pro- dução capitalistas. No entanto, os programas contraideológicos, se são eficazes no desmascaramento das ludibriações ideológicas, são também ineficientes para alterar a situação revelada.

Tal ponderação poria em xeque também o princípio psicanalítico segundo o qual bastaria trazer à consciência o trauma recalcado para superá-lo, para alterar determinado padrão de comportamento. Mas tal registro fica aqui a título de exemplo de um mecanismo rechaçado pelo filme.

Como foi dito, de nada vale ao Jack saber que ele e Durden são a mesma pessoa. Durden não desaparece. A revelação não o cura. Não basta saber da ilusão, é preciso combatê-la, lutar contra ela. Nesse sentido, o filme não crê na eficiência de sua crítica ao consumismo, como se sua denúncia pudesse alterar a realidade social. Mais perigosa parece ser a mensagem (subliminar como o pênis que aparece no final?) de que a destruição pré-existe qualquer nova ordem.

É possível, portanto, supor que o filme defenda a violência como potencial criador. Mas é muito difícil crer que, aceita tal inferência, seja esse saber realmente transformador. Prefiro ficar com as palavras de Jack-Durden, "você me conheceu numa época estranha da minha vida", e assistir ao filme como uma fábula sobre a peleja do real contra a ilusão do duplo.

\section{Referências}

BANDEIRA, Manuel. Estrela da vida inteira. Rio de Janeiro: Nova Fronteira, 2009.

CAMUS, Albert. O Homem Revoltado. Rio de Janeiro: Record, 2008. 
DURAND, Gilbert. Science de I'homme et tradition: Paris, Berg International, 1979.

FREUD, Sigmund. 0 mal-estar na civilização. Vol. XXI. Rio de Janeiro: Imago, Ed. Standard Brasileira das Obras Completas, 1974.

LIPOVETSKY, Gilles. A Era do Vazio. Lisboa: Relógio D'Água, 1989.

MAFFESOLI, Michel. Tempo das tribos: declínio do individualismo nas sociedades de massa. Rio de Janeiro: Forense Universitária, 1998.

PALAHNIUK, Chuck. Clube da Luta. Trad. Vera Caputo. São Paulo: Nova Alexandria, 2000.

POE, Edgar Allan. Os melhores contos de Edgar Allan Poe. São Paulo: Círculo do Livro, 1989.

RIBEIRO, Paulo Jorge. A era da frustração: melancolia, contra-utopia e violência em Clube da luta. Rev. Antropol. [online]. Vol.45, n.1, p. 221-241, 2002.

ROSSET, Clément. $\mathbf{O}$ real e seu duplo: ensaio sobre a ilusão. Rio DE Janeiro, José Olympio, 2008.

UNAMUNO, Miguel de. Do sentimento trágico da vida no homem e nos povos. São Paulo: Martins Fontes, 1996.

\section{Referências audiovisuais}

FINCHER, David. Clube da luta. [Filme-vídeo]. Produção de Ross Grayson Bell, Cean Chaffin e Art Linson, direção de David Fincher. EUA, 1999. 139 min. color. son.

KUBRICK, Stanley. Laranja mecânica. [Filme-vídeo]. Produção e direção de Stanley Kubrick. EUA, 1971. 136 min. color. son.

\section{Notas}

1 Doutor em Educação pela Universidade de São Paulo. Professor do Departamento de Administração Escolar e Economia da Educação da Faculdade de Educação da Universidade de São Paulo (FEUSP - Av. da Universidade, 308, CEP.: 05508-040, Cidade Universitária, São Paulo - SP, Brasil). E-mail: rogerioa@usp.br. 